\title{
Kinesthetic Game Model to Improve Early Mathematical Ability in Early Childhood
}

\author{
Setiyo Utoyo \\ Universitas Negeri Gorontalo, Gorontalo, Indonesia \\ e-mail: setyo.utoyo@gmail.com
}

\begin{abstract}
The purpose of this research is to develop kinesthetic game model in improving early math ability in group B TK Damhil Gorontalo.

The method used is research and development, developed by Borg and Gall. Model development is done through the requirement analysis phase, product development and testing. After a number of experiments, input from teachers using this model is fun, meaningful, has health value and expert advice adds a more cognitive and constructive thinking style. The effectiveness of the model test shows a significant improvement in the process of assisting children with early mathematical abilities in early childhood (Kindergarten). The results of this study are kinesthetic product models in the form of guidebooks, teaching materials, media and assessment
\end{abstract}

Keywords: Early Mathematics, Kinesthetic Games

\section{INTRODUCTION}

Mathematical ability is one of current phenomenon talked by all people particularly in parents' group. One of purposes the parents register their children in PAUD (Early Childhood Education) institution is making the children master mathematics. Lots of parent, still, consider that smart kids are those who master or capable in calistung (reading, writing and counting) as early as possible. The parents are worried about their children in regard of mathematical mastery due to one of school admission tests is the mathematical mastery.

Jamaris (2009) thinks that mathematical ability is one of abilities obtained from varied processes and it is not mastered suddenly. Development of person's mathematical ability is based on stages of the person herself/himself. Children's mathematical ability requires to be developed with varied processes which are able to stimulate properly thus the ability is optimally developed.

Piaget in Subarinah (2006) states that, early children's mathematical ability is performed through three level of stages: 1) level of concept understanding namely the children will understand certain concept through experience of doing activity/ play with real objects, 2) level of transition namely process of thinking transition from real understanding to introduction of abstract symbol, where the real objects are existed and started to introduce form of the symbol, 3) level of number symbol namely opportunity to know and visualize number symbol towards real concept they understood.

In theory of mathematical learning of Dienes or known as Joyful learning, it explains that person's learning process is observed from level of the cognitive ability, in teaching and learning process, level of cognitive becomes one of important things due to it depends on person's age, thus learning for adults is different with children's.

Based on finding of preliminary study in several Kindergartens in Gorontalo area (Kindergarten, henceforth called by TK, TK Damhil, TK Negeri Pembina Ki Hajar Dewantoro, TK AL Murqi, TK Al Islah, TK Al Wirabuana and TK Raudhatul Jannah) in semester II academic year of $2016 / 2017$ and finding of interview with teachers and principals of Kindergarten, it shows that issue of high parents' demand becomes obstacle which causes learning activity abandonment particularly in development of mathematical based on what is supposed to be, due to parents consider play activity is not important for the children as the parents think that truly learning is doing several Students' Worksheet in classroom. They want their children master reading, writing and counting before entering 
further school level. This causes teachers are dilemma to use play in stimulating development of mathematical ability in every learning activity.

Issue of early mathematical development in early children is found in TK Damhil City of Gorontalo. Here, based on five indicators of children's early mathematical ability observed by researcher, namely classifying, matching, arranging, comparing and numbering, $27 \%$ out of 20 observed children have good criteria for early mathematical ability, $42 \%$ of them have sufficient criteria for early mathematical ability and $31 \%$ of them have less criteria for early mathematical ability. Based on the data, children's early mathematical ability in group B1 of TK Damhil City of Gorontalo is still in low category (Observation in April 2017).

Research finding of Mooney, et.al (2009) showed that children learn mathematics through games and exploration such as telling story, singing, kinesthetic, imaginative and role playing. These methods are more interested and joyful due to students are involved in activities of their world. Game for children is very important due to it can develop creativity, practice kinesthetic, practice concentration, persistence and body endurance for balance of the body.

Based on the previous background, the researchers are interested in designing game model particularly in development of early children's mathematical ability. Then, development activity of children's mathematical ability can be performed through kinesthetic game. Kinesthetic is an ability to express idea, strength/ power, skill and him/herself related to body movement. In kinesthetic game, children love things related to movement such as sport, art (pantomime, acting and choreographer) and hand skill.

The applied kinesthetic game is expected that can develop children's early mathematical ability namely fun game, where children involved directly. Activity in kinesthetic game is more focused on rough motoric activity.

Generally, definition of mathematics is an ability which can be mastered by someone in solving several daily cases. This is related to patterns, order, classification, size, concept of number, one to one correspondence, concept of geometry form, doing estimation and processing simple data by manipulating and using real media before operating abstract symbols as well as doing interaction through games.

Susan Smith (2009) in her book mentions that there are several concepts of early children mathematics namely a) matching the concept of one to one correspondence, b) classification c) comparing and d) ordering or seriation. This opinion explains that mathematics for early children is started from children learn to match, classify or place objects based on certain form or category, compare and similarity. Kennedy (2008) states that concept of mathematics is a) matching and discriminating, comparing and contrasting, b) classifying, sorting and grouping, c) ordering, sequence and seriation.

In introducing to children, it is easier if they are given opportunity to experience themselves either using real objects due to in this stage they learn to use symbols and they are not able to think systematically.

Minetola (2014) mentions several mathematics stages of early children are started from small number recognition, meaningful object counting, increasing magnitude concept and counting based comparison, number after knowledge, comparison of neighboring numbers, number after equals 1 more, mentally adding 0 and 1 , mentally adding 2 to 5 . This opinion means that introduction to small number refers to learn to count, increase concept of counting based on ability in dividing number, divide close numbers, after that multiply number 1 or more, add number 0 and 1 , add number 2 to 5 .

Based on previous elaboration, it explains that early mathematical ability has stages required to be recognize in order to ease the researchers to determine activity properly and appropriately based on early children.

Hurlock in Musfiroh (2008) states that playing is an activity which is performed only for fun without considering final result. Santrock (2012) states that playing is a fun activity performed for the sake of importance of the activity itself. Meanwhile, Freud and Erikson in Santrock (2012) state that playing is as a media to improve cognitive development of children. Referring to previous several opinions, kinesthetic game in this research is a game performed in form of kinesthetic movement in improving early children's mathematical ability.

Kinesthetic game is a skill with movement characteristics which involves big muscle and it contains no certain purpose. Like fundamental movement of kinesthetic skill such as walking, jumping and throwing.

Formation process of movement in human does not occur automatically, instead, it is accumulation of learn and practice namely by understanding movement and doing it repeatedly and it is followed by awareness of between right or 
wrong of the movement. Therefore, motoric skill is an ability of doing movement efficiently and effectively. In general, skill is a term mostly related to someone as skill to do specific purpose (Ricard, 1998).

This research will develop 5-6 yo children mathematical ability through kinesthetic game. The activity is performed through activity which involves children directly in the game designed/ planned by the researcher. Learning as a game which involves movement of rough motoric in children, in the activity is designed by referring to development of mathematical concepts based on their age.

Kinesthetic game is simulated with motoric movement game of balance mastery, dynamic movement and motoric skill. Thus, children will be comfortable and happy as well as interested to follow the activity. This condition will ease children in absorbing new information about mathematical concepts simply.

Through kinesthetic game, instead of mathematical ability, children can be skillful, and their skill and attitude cab be developed simultaneously. Skill, in this case, can be singing, motoric skill even attitude can be instilled from early. Children attitude can be observed in form of how they are able to obey rules in the activity, mutual respect in group activity, sensitiveness towards others or sympathy, and how their attitude in accepting loss and victory in the game.

Then, early children's mathematical ability developed by researchers in this research through kinesthetic game is based on above fundamental theories namely: 1) ability of classifying object, 2) ordering, 3) separating and 5) comparing.

\section{METHODS}

This research uses research and development procedure by having method refers to research model of Borg and Gall in Abdullah, 2008 which consists of five steps namely: 1) doing analysis product that will be developed, 2) developing early product, 3 ) validating of expert and revision, 4) doing small scale field trial and product revision, and 5) big scale trial and final product.

Research samples are determined by purposive sampling and the samples are chosen by the researcher after conducting preliminary study in TK in Gorontalo area. They are TK Damhil as first trial and TK Al Murqi and AL Izlah as second trial.

Technique of collecting the data uses 1) check list of field observation through observation sheet and interview, 2) check list of assessment towards early mathematical ability of TK children, 3) questionnaire, 4) instrument of expert assessment, 5) field note, 6) questionnaire as assessment instrument, and 7) check list of assessment towards early children's early mathematical ability. Instruments of early children's early mathematical ability in the research are observation, questionnaire and test. Technique of analyzing data uses qualitative analysis when data collection is ongoing and after data are collected in certain period by summarizing data to choose main and important things. Quantitative data obtained from questionnaire are analyzed by using descriptive analysis with percentage, while data of test result (pre test and post test) about early mathematical ability of TK children are analyzed by $t$ test.

\section{RESEARCH FINDINGS}

Finding of research and development is finding of preliminary study conducted in several TK in Gorontalo area found that teachers do not have yet particular method in handling issue on early mathematical ability in children. The applied ways run conventionally such as teachers mostly give instruction, they used to write on the whiteboard, they still use old tradition which focuses on classroom activity or they do not do outdoor activity in learning mathematics.

Thus, it can be concluded that kinesthetic game is an innovative model to improve early mathematical ability in Gorontalo area. Kinesthetic game model is designed through deep theoretical review process and it will be conducted several times for field trial.

Finding of implementation of trial for kinesthetic game in development of children's mathematical ability in TK Damhil Gorontalo show pleased fact. Children look happy in following this learning model and their finding of mathematical learning improves significantly. Based on the finding, thus for next, the researcher will develop a model by doing wide trial to several TK in Province of Gorontalo as well as dissemination model.

This model is developed by concerning characteristics of early children as well as facilitating different learning style and have been through process of expert validation. The model of kinesthetic game is completed by guideline book, play media (APE) and learning media of early children's early mathematical ability. Finding of recommendation for peers and expert validation obtain conclusion that is product of kinesthetic game model is practical and effective to be used by 
teachers, as well as effectiveness of the developed model.

Based on research findings, it found that handling of learning issue on early mathematical ability in children requires teachers' mastery, either in optimizing media in order to be more interested and fun or in using social-emotional approach. Topic delivery should be based on children's life context and creating creation and imaginative in learning.

\section{CONCLUSIONS}

Based on preliminary study and finding, it obtains following conclusions:

1) teachers do not have yet particular method in handling issue on early mathematical ability in children. The current ways run conventionally, such as teachers mostly give instruction, they used to write on the whiteboard, they still use old tradition which focuses on classroom activity or they do not outdoor activity in learning mathematics.

2) Kinesthetic game model is designed through deep theoretical review process and several times of field trial process. This model is developed by concerning characteristics of early children as well as facilitating different learning style and have been through process of expert validation. The model of kinesthetic play is completed by guideline book, play media (APE) and learning media of early children's early mathematical ability. Finding of recommendation for peers and expert validation obtain conclusion that is product of kinesthetic play model is practical and effective to be used by teachers, as well as effectiveness of the developed model.

3) Finding of kinesthetic game model trial in first stage is conducted in Group B of TK Damhil City of Gorontalo proves that effectively, kinesthetic game model can improve early children's early mathematical ability.

\section{REFERENCES}

[1] D. Gall, Meredith, Joy Gall, and Wolter R. Borg, 2003, Education Research and Introduction, Boston: Pearson Education, Inc

[2] Jamaris Martini, 2009, Kesulitan Belajar "Perspektif, Asesmen dan Penanggulangannya" Jakarta: Yayasan Penamas Murni.
[3] Minetola R. Janice, Robert G. Xiegentuss, And J. Kent Chirman. Teaching Young Childrens Mathematics. First Published 2004. New York: Rouledce. (on line book)

[4] Musfiroh Tadkiroatun.2008. Cerdas Melalui Bermain (cara Mengasah Multiple Intelligence Pada Anak Usia Dini). Jakarta:Grasindo.

[5] Mooney, Claire., Briggs, Mary., Fletcher, Mike., Hansen, Alice., McCullouch, Judith. 2009.Primary Mathematics: Teaching, Teory, and Practice. Exeter: Learning.

[6] Oers Van Bert. 9 Juni 2011. Are You Sure Stimulation Mathmatical Thingking Gurung Young Childrens Play. University Amsterdam.

[7] Ontario.

www.edu.gov.on.ca/eng/literacynumeracy inspire/. Capacity Buliding Series Maximizing Student Mathematical Learning in the Early Years. ISSN: 1913 8482 (Print) ISSN: 19138490 (Online)ca/eng/literacynumeracy/i.

[8] Russefendi E.T, 2001, pengantar untuk membantu guru mengembangkan kompetensinya dalam pembelajaran matematika untuk meningkatkan CBSA, Bandung: Transito

[9] Subarinah, 2006, Inovasi Pembelajaran Matematika SD, Jakarta: Depdiknas

[10] Susan Sperry Smith. 2013. Early Childhood Mathematics.United States of America: Pearson.

[11] Santrock, John W. 2012. Life-span Development. 13 th Edition. University of Texas, Dallas : Mc Graw-Hill 